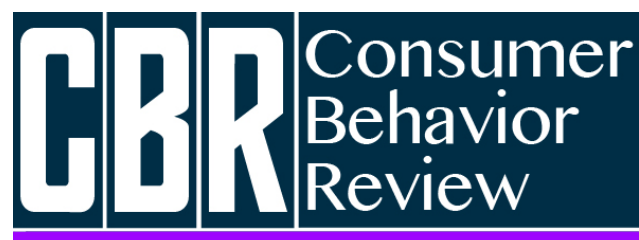

Revista Comportamento do Consumidor
Neves, A. L., \& Rezende, D. C. (2021). "Whoever Sees You Pass By Me Like This": The shaping of identity and consumption of fans of the band Los Hermanos. Consumer Behavior Review, 5(2), 261-277.
ISSN: 2526-7884

Editor: Prof. Dr. Marconi Freitas da Costa

E-mail: cbr@ufpe.br
Evaluation: Double blind review

Received: February 03, 2021

Accepted: April 17, 2021

\title{
"WHOEVER SEES YOU PASS BY ME LIKE THIS": THE SHAPING OF IDENTITY AND CONSUMPTION OF FANS OF THE BAND LOS HERMANOS
}

“Quem Te Ver Passar Assim Por Mim": Formação de identidade e consumo dos fãs da banda Los Hermanos

\author{
André Luiz Neves ${ }^{1}$ \\ ORCID: http://orcid.org/0000-0002-6332-7698 \\ E-mail: andreluiz_neves@yahoo.com.br \\ Daniel Carvalho de Rezende ${ }^{2}$ \\ ORCID: http://orcid.org/0000-0003-1277-724X \\ E-mail: danielderezende@ufla.br
}

\begin{abstract}
${ }^{1}$ Instituto Federal de Educação, Ciência e Tecnologia do Sul de Minas Gerais, Machado, Minas Gerais, Brasil
\end{abstract} ${ }^{2}$ Universidade Federal de Lavras, Lavras, Minas Gerais, Brasil

\begin{abstract}
The objective of this work was to characterize and describe the dimensions of the identity of fans of the Brazilian band Los Hermanos and its influence on consumption and on the extension of the self. A qualitative approach was used in a case study. First, bibliographic materials such as interviews, song lyrics, products, information from the official website, and fan posts on social media pages were analyzed. Subsequently, the relationship of the fans with the band Los Hermanos and the consumption patterns for related products and services were analyzed. Individuals aged between 25 and 45 were interviewed who, in their youth, had bonded with the band, developing and maintaining their appreciation
\end{abstract}

\begin{abstract}
Resumo
Com este trabalho tem-se o objetivo de caracterizar e descrever as dimensões da identidade dos fãs da banda brasileira Los Hermanos e sua influência no consumo e na extensão do self. Utilizou-se a abordagem qualitativa por meio de um estudo de caso. Num primeiro momento, foram analisados materiais bibliográficos como entrevistas concedidas, letras de músicas, produtos e informações do site oficial, além de posts de fãs em páginas de redes sociais. Posteriormente, buscou-se analisar a relação dos fãs com a banda Los Hermanos e os padrões de consumo de produtos e serviços relacionados. Foram entrevistados indivíduos com idade entre 25 e 45 anos que, na
\end{abstract}


for the band until the present day. It was found that the fans consider themselves to be romantic and reflective, and they identify with the band's lyrics; however, they do not have an exacerbated need to show their status as a fan because, over the years, they have managed to associate themselves with their own fan status. The fact that the band has finished its activities but occasionally returns for concerts reinforces the fans' passion through the nostalgic effect, and it invigorates the consumption of associated products and services.

Keywords: Music; Consumption culture; Music Consumption; Image; Self extension. juventude, tiveram contato com a banda, desenvolvendo e mantendo o apreço pela mesma até os dias atuais. Verificou-se que os fãs se consideram românticos e reflexivos, se identificam com as letras da banda e não têm a necessidade exacerbada de demonstrar a sua condição de fã por já terem conseguido ao longo dos anos associar seu self com a condição de fã. 0 fato da banda ter encerrado suas atividades, mas retornar pontualmente para shows, reforça a paixão dos fãs por meio do efeito nostálgico e revigora o consumo de produtos e serviços associados.

Palavras-chave: Música; Cultura de consumo; Consumo de música; Imagem; Extensão do self.

\section{INTRODUCTION}

Cultural consumption is one of the main forms of identity construction in contemporary society. In the field of Consumer Culture Theory (CCT), consumers identity projects are one of the main research areas (Arnould, \& Thompson, 2005; Gaião, Souza, \& Leão, 2012). In this sense, some studies try to understand the phenomenon of cultural consumption focusing on the identity projects of the consumer/fans (Larsen, Lawson, \& Todd, 2009).

Regarding identity, the demonstration of taste, whether in digital media or in personal relationships, is used as a form of social differentiation and classification (Ter Bogt et al., 2011). Moreover, when it comes to cultural consumption one important concept is the fandom, a subculture in which a group of fans of an artist share (in online or offline environments) their opinions, beliefs and preferences (Cavalcanti, de Souza-Leão, \& Moura, 2021; Guschwan, 2012).

One of the cultural fields that is most popular and, consequently, most related to the question of taste and identity is the field of music (Ter Bogt et. al, 2011, Cavalcanti, de Souza-Leão, \& Moura, 2021). The relationship with music very much depends on the way in which people listen. On the one hand, circumstantial and uncommitted listening to music does not generate empathy with it, much less contribute to the formation of the listener's identity. On the other hand, in-depth listening culminates in producing in the individual some result or change in their way of thinking and acting, thus collaborating in creating their personality and enabling the expression of their convictions within society.

One way in which music is used to build identity projects is through musical taste, which is usually related to the groups to which a person belongs and through which the person is defined (Larsen, Lawson, \& Todd, 2009; Suess, 2016). In the context of the movements, subcultures, or urban tribes that have formed from the various musical genres, the imaginary is based on the engagement of individuals who wish to consciously and critically participate in a certain narrative, identifying with certain images, symbols, myths, or roles related to artists and musical groups (Anaz, 2013).

Another way to build identity through music is through its consumption. For Boorstin (1973), individuals ultimately consume products and services related to the musical genres or artists they like; that is, consumption refers not only to the music itself but also to products such as clothing, accessories, experiences, and places related to the music. Therefore, through consumption, people also relate to the music and define their behavior and thinking (Belk, 1988; Boorstin, 1973).

In this context, of particular note is the case of the Brazilian band Los Hermanos, which, with only one decade of existence (1997-2007), has conquered and continues to conquer a legion of admirers, even after finishing its activities. From its beginning to the present day, thousands of people 
have identified with the songs, the ideas, and the behavior of the band's members, seeking to repeat such behaviors and share them through their consumption and social interaction.

Los Hermanos is a Brazilian rock band that formed in Rio de Janeiro in 1997 that mixed rock with elements of Brazilian music such as samba and MPB (Brazilian Popular Music), as well as other rhythms such as ska and hardcore. The band became nationally known on their first album through the hit Anna Julia, which was one of the most played on the radio between 1999 and 2000 (Gajanigo, 2016). They subsequently increased their fan base and gained critical acclaim with the albums Bloco do Eu Sozinho (2001), Ventura (2003), and 4 (2005).

For Gajanigo (2016), the work of the band seems paradoxical, at the same time that there is a reduction in singing, it expands the reference in the instrumental element, making it the channel of insertion of diverse rhythms and traditions. In April 2007, the band announced an "indefinite hiatus", alleging the accumulation of many personal projects of the musicians. However, they returned for concerts in various Brazilian cities in 2009, 2012, and 2015, with a huge impact and tickets selling out.

Given the prominent position of Los Hermanos in the Brazilian music scene, the significant number of people who identify with the band and their willingness to consume tangible and intangible goods related to the musical group, the idea was to answer the following research question: How is the identity of the fans of the band Los Hermanos formed? Additionally, what are the main patterns for the consumption of goods and services related to this musical group? The main objective was to characterize and describe the dimensions of the identity of the fans of Los Hermanos and their influence on the consumption and the extension of self.

\section{MUSIC AND IDENTITY}

To understand the various issues pertaining to the consumption of music, this item will discuss the symbolic consumption related to the extension of the self, the subculture of the fans, and the ways in which music influences the construction of identity and the extension of self.

\section{Symbolic consumption and extension of self}

Consumer society treats objects as object-symbols, which are consumed for their symbolic value, and not only for their utility (Gaião, Souza, \& Leão, 2012). In this scenario, signs and images develop an explicit relationship with consumption culture. Consumer goods come to be understood as the visible part of the culture, allowing individuals to engage meaningfully with other consumers and with society (Douglas \& Isherwood, 2002).

For Belk (1988), we are what we have, and this notion may be the most basic and powerful fact of consumer behavior. For him, the concept of the extended self occurs through control and domination, creation, knowledge, and the closeness and habituation with an object. More broadly, extending the self refers not only to possessing a product or assigning value to it. This extension implies a strong connection with the symbolic meaning between the good possessed, the identity of the individual, and the definition of oneself. Through consumption, individuals express themselves and view their possessions as a part or extension of themselves (Barboza \& Ayrosa, 2013).

Moreover, the concept of the extended self is not limited to external objects and personal possessions, but it also includes people, places, and belonging to a group, as well as possessions such as body parts and vital organs (Belk, 1988). Still according to the author, the notion of an extension of the self includes not only what is seen as the representation of the self but also what is seen as mine.

One of the main ways of expressing and defining group participation is through the symbols of shared consumption. Just as clothing, language, ornaments, and accessories can distinguish an individual from others and express an individual mode of being, they can also indicate the identity of the group and express the belonging to it (Belk, 1988; Boorstin, 1973).

Finally, five changes resulting from the current digital age must be understood to promote the update on the extended self: dematerialization of things, reincorporation due to the loss of limitation of physical bodies, massive sharing of data and information, co-construction of the self in interaction with other people and autobiographical memory sparsely distributed. These changes must be 
evaluated in terms of implications for understanding the self, the nature of possessions and our relationships with things in a digital world (Belk, 2013).

\section{Subculture of fans}

In the 1980s, before the earliest studies on the theme, the term fan was understood to refer to an extremely devoted follower who had an obsessive attachment to artists or media texts, emphasizing the fanatical aspect in the etymology of the word (Reijnders, ZWaan, \& Duits, 2014). This form of identification was defined by Devlin, Billings and Leeper (2016) as an orientation of the self in relation to other objects, including a person or group, which results in feelings of attachment or closeness, making the individual feel a psychological connection, or even a sense of belonging and attachment to a larger social structure.

In midst of this context, it is also important to highlight the subculture issue of fans who share common tastes and empathetically relate to other members of their community (Ulusoy, 2016). Subcultural groups are an imaginary community with individuals who share the same ideas, religion, habits, or the same tastes. Subcultural groups transform individuals into proactive people and producers of meanings and experiences who are not only consumers. Such groups allow their members to emancipate themselves from the logic of the market. A subculture can be experienced as an extension of a person (Duffett, 2015; Ulusoy, 2016; Hellekson, 2018).

It is in the community that fans establish their practices, seeking to be an active part of the entertainment industry. In these spaces, their discursive practices expand, transforming their consumption experiences into truths about products and identity practices. (Cavalcanti, de SouzaLeão, \& Moura, 2021).

For Chen (2018), the consumption of cultural products has adopted new perspectives, different from the common consumption of mass culture, the so-called "prosumption", which provides the collector with a sense of accomplishment and creates spaces for prosumers to negotiate their desired identities. According to Fuschillo (2020), in recent times, studies on media fandoms have evolved from the idea of fandoms as distinct entities to the idea of fandoms as a dynamic and interactive process with society.

Thus, the relationship between the power of the cultural industry and consumers has been changing, moving from a linear or asymmetric relationship to a two-way relationship. This allowed consumers to become producers at certain points, producing cultural texts from their own creation (Sugihartati,2020).

The notion of memory in the field of music is relevant because there seems to be an intention to create a bond with the public through the repetition of lyrics and beats and through similarity with an artist's aesthetics and the omnipresence of their image. A narrative is projected with the goal of creating a nostalgic need in the fan. Thus, it is in the repetitions, reenactments, and reiterations of behavior that there is an intention to propel fans' memories to sustain a fictitious place in their minds, a sense of belonging (Mascarenhas, 2016).

\section{Construction of identity and extension of self through consumption of music}

It is widely accepted that music can be used as a tool for communicating an extra musical symbolic meaning; however, there is still little understanding of the processes involved in selfrepresentation through music. Thus, there is still much to be investigated in relation to selfrepresentation through the consumption of music (Boer et. al., 2012; Larsen, Lawson, \& Todd, 2009).

According to Suess (2016), music is a cultural code that significantly promotes social and cultural unity, with the power to unite groups and enable their identity to be recognized and widely disseminated. The various musical genres and subgenres have been vectors of diverse "tribes" in different cultures. Many of these groups establish themselves as emotional communities whose participants share the imaginary that emerges from the music and establish processes of cultural identification around this imaginary (Anaz, 2013).

The music audience is often characterized by a sense of community and belonging, giving the impression that communities of music fans are cohesive, unique in nature and purpose, and devoid of 
intergroup tensions. However, the anti-fans or haters, are individuals who are not necessarily against fans, but do not like a certain text or genre strongly, considering it inane, stupid, amoral or aesthetic nonsense (Obiegbu, Larsen, \& Ellis, 2019).

Thus, Larsen, Lawson and Todd (2009) conducted a study with the main objective of describing the experience of some individuals while using music as a means of representing themselves in social interactions. Their study culminated in the elaboration of a conceptual framework for music consumption (Figure 1):

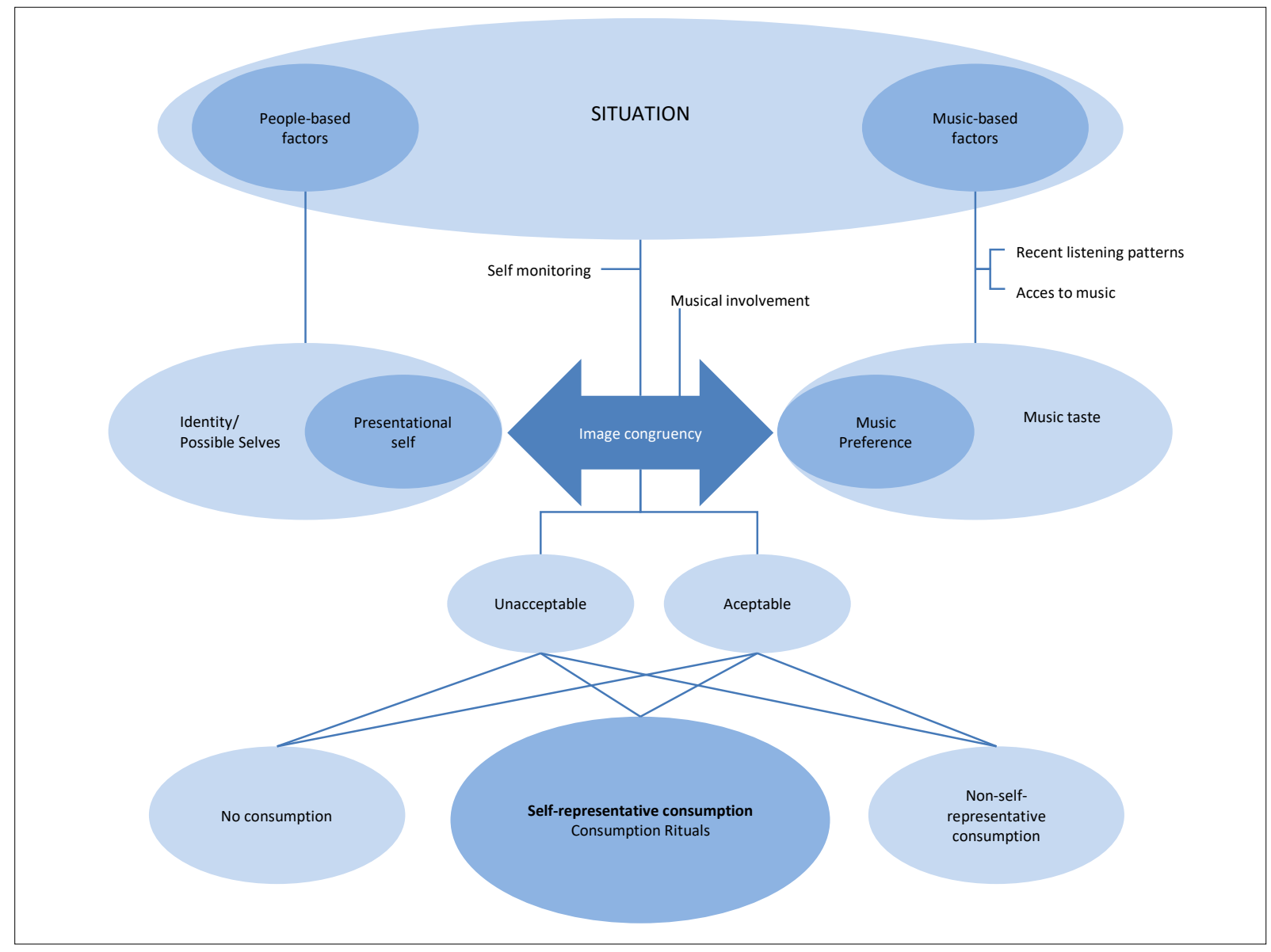

Source: Adapted from Larsen, G., Lawson, R., \& Todd, S. (2009).

Figure 1. Larsen, Lawson, and Todd (2009) conceptual framework for music consumption as self-representation

The basis of the conceptual framework is the comparison of the image of the music of preference with the representation of the self of an individual. It is at this point that the congruence between these two images and the acceptability of conformity are evaluated. Regardless of this context, there are three consumption options: no consumption, consumption that is non-selfrepresentative, and self-representative consumption. Music can be used to represent the self when the comparison is acceptable (e.g., when the image of the music is congruent with some aspect of the self), or when the comparison is unacceptable (e.g., when the comparison is congruent but unacceptable, such as listening to an unpleasant song or expressing disgust for some artist or type of music). Additionally, an acceptable or unacceptable comparison may also generate a result in which the music is consumed in a way that is not self-representative (i.e., without reference to the self) or simply not consumed (Larsen, Lawson, \& Todd, 2009).

Thus, in accordance with the conceptual framework of Larsen, Lawson and Todd (2009) shown in Figure 1, a theoretical scheme of analysis for this present article, shown in Figure 2, was elaborated: 


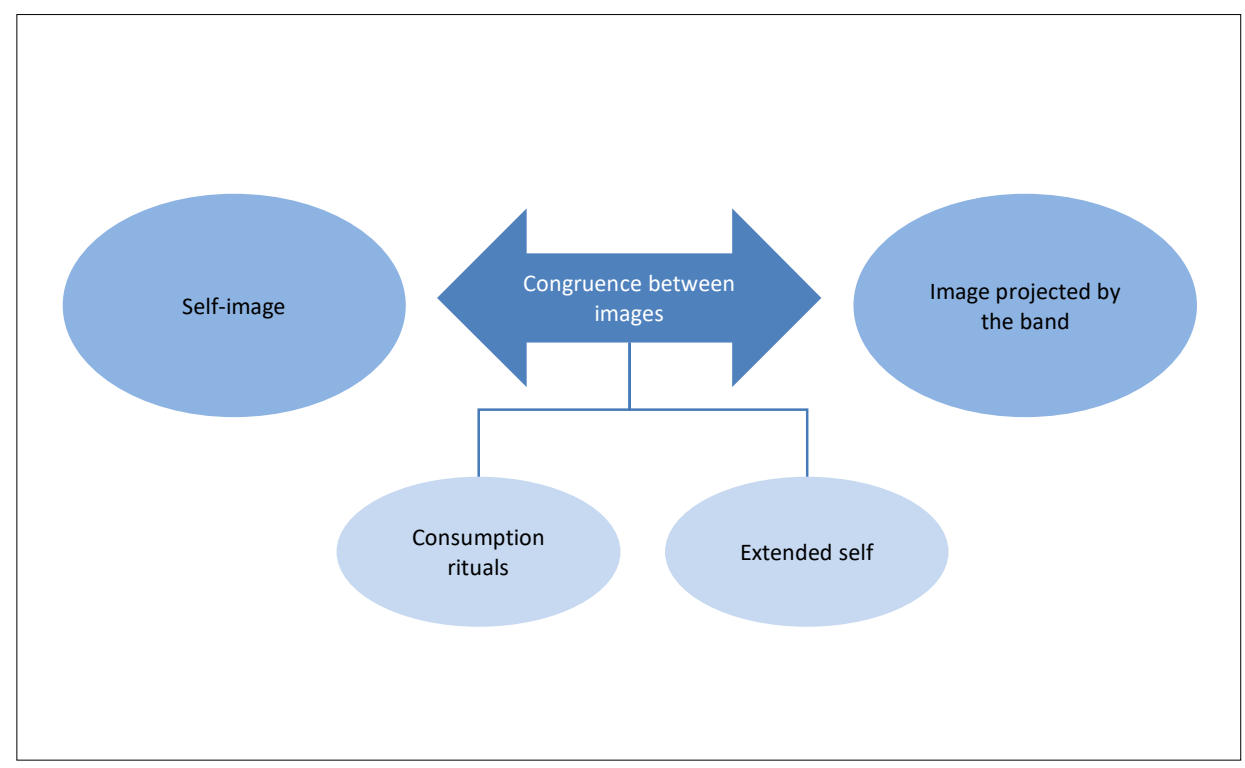

Source: Elaborated by the authors.

Figure 2. Theoretical scheme of analysis for the study

Based on the theoretical scheme, the study aimed to identify the congruence between the image projected by the band and the self-image of the fans that materializes through the consumption rituals and the means by which the self is extended.

\section{METHODS}

In this section, the objective is to present the characteristics of the study conducted. From the point of view of addressing the problem, the research is qualitative, as it aims to understand the phenomenon under study from the perspective of the people involved in it (Los Hermanos fans), raising in-depth information that makes it possible to understand the habits and attitudes of consumers when investigating subjective aspects as feelings, thoughts, intentions and behaviors (Miles, Huberman \& Saldaña, 2018).

For this understanding, the research was carried out by the conjunction of long interviews, following the molds proposed by McCracken (1988), as well as the analysis of documentary data available on websites (Denzin, Lincoln, 2011). Previous work in the areas of CCT and fandom, such as Cavalcanti, Souza-Leão, \& Moura, (2021), Chen (2018) and Souza-Leão et. al. (2020), also used these types of analysis in their analysis. Figure 3 summarizes the main characteristics of the research methodology:

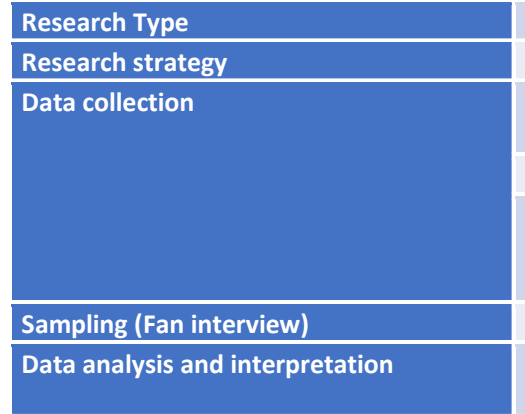

Qualitative Descriptive

Case study - Fans of the band Los Hermanos

Speech of the band and products offered - lyrics, official

website, page in social networks, interviews granted;

What is said by fans - posts on social network;

Interview with fans - Interviews with fans selected on

the web and/or indicated by other fans (snowball sampling).

Saturation criterion

Content analysis (secondary and primary data) with

mixed grid

Source: Elaborated by the authors.

Figure 3. Methodological characteristics of the study 
To better elucidate the questions related to the study, the data collection procedures and techniques will be described first, followed by the data analysis and interpretation techniques.

\section{Data collection procedures and techniques}

First, various materials related to the history of the band Los Hermanos, the discourse of its members, the products offered, and the activities and declarations of its fans were analyzed. For this, the interpretative content analysis proposed by de Souza-Leão et. al. (2020) was used, which advocates the selection of data based on its relevance to the phenomenon to be investigated, going beyond the purely lexical and semantic levels that characterize the approaches more traditional content analysis. This analysis was useful for conceiving the environment of the phenomenon and to understand the habits of the followers, which served as the basis for the conducting of interviews with the band's fans.

Second, interviews with fans of the band were done digitally, using video conversation programs and applications. To facilitate the subsequent analysis of the data, all content was recorded subsequent to the consent of the interviewees. Nonprobabilistic snowball sampling was used. The first interviewees were identified through the social circle of the researcher, either through intermediation of the public who attended the classification of the study project and indicated friends who are fans of the band, or through people already known by the researcher and who appreciate the band's work.

Confirming the large number of individuals of this population: there are currently 1,215,249 followers registered on the band's official page on Facebook (@Los.Hermanos.Oficial). Because of this, the "Los Hermanos" page was also used as the first point of contact with some fans of the band.

In addition to the initial contacts, the posts made by fans on the band's official Facebook page were also used as a source of information and illustration of the fans' relationship with the band. However, as there was no systematic structured and in-depth analysis of the posts, only their reading, the research cannot be considered as a netnography.

As a delimitation of the sample, individuals - of both sexes and aged between 25 and $45-$ were interviewed, who, in their youth, had contact with the band at the height of their trajectory, developing and maintaining their appreciation for the band until the present day. Regarding the sample size, the saturation criterion was used, identifying - during data collection - the point at which little additional information emerged from a new interview. Thus, 21 in-depth interviews with an average duration of 40 minutes - were conducted from December 12, 2017 to March 31, 2018.

To contrast the views of the fans with those of the band itself in relation to certain themes of the study, it was sought to contact the representatives of the group, or even the musicians themselves. Vocalist Marcelo Camelo replied to the first email sent, revealing his opinion regarding three questions. Subsequently, a few more contacts were made to clarify new issues.

\section{Analysis and interpretation of the data}

The information obtained through interviews and secondary data (the band's website, social networks) was subjected to a content analysis with a mixed classification with the aim of identifying the preferences related to the consumption of band-related goods, as well as the characteristics of the identity and sociological profile of the fans. Figure 4 summarizes the main analysis categories of the study. 


\begin{tabular}{|l|l|l|}
\hline Personal identity & $\begin{array}{l}\text { Self-image } \\
\text { Relationship with the band } \\
\text { Image of other fans and relationship with them }\end{array}$ & $\begin{array}{l}\text { (HALL,2006); } \\
\text { (ORTIZ,2006). }\end{array}$ \\
\hline $\begin{array}{l}\text { Identity passed on by the } \\
\text { band }\end{array}$ & $\begin{array}{l}\text { Band image } \\
\text { Song Lyrics } \\
\text { The haters }\end{array}$ & $\begin{array}{l}\text { (LARSEN;LAWSON; } \\
\text { TODD,2009);(REIJNDERS; }\end{array}$ \\
\hline $\begin{array}{l}\text { Congruence and } \\
\text { extension of self }\end{array}$ & $\begin{array}{l}\text { Self-image X Image of the band and its fans } \\
\text { Consumer Rituals } \\
\text { Self extension }\end{array}$ & (LARSEN;LAWSON; \\
\hline
\end{tabular}

Source: Elaborated by the authors.

Figure 4. Analysis categories

In addition to the preliminary categories aligned with the study objectives, other categories that emerged from the data during the analysis process were also identified, for example, the nostalgia generated by the separation of the band and the characteristics of the "mature fan".

\section{THE FANS AND THEIR RELATIONSHIP WITH LOS HERMANOS}

In this section, the main results obtained through the study are presented and discussed. To better understand and fulfill the objectives proposed by the study, the data were analyzed from three different perspectives, which are represented in the following sections: Personal identity, Identity passed on by the band, and Congruence and extension of self.

\section{Personal identity}

The main perceptions obtained through the study regarding the interviewees' image of themselves and other fans, as well as the relationship with the band and with those who also admire it, are presented below.

\section{Self-image of the fans}

Defining one's own image is complex for any human being, and this was specifically the first request of each of the interviewees, to either indicate the reflective path of the study or to encourage them to express their innermost selves. Through the answers, the plurality of the identity characteristics of the informants could be seen, revealed by traits such as shyness in the midst of society, determination in the pursuit of goals, and constant reflection in the midst of various day-today situations. Among the various self-definitions, we can highlight:

"Human. Introspective. Sensitive. In my way of being.

Complex. Dense. Hermetic. In my way of acting.

Contemplative. Detailist. Subtle. In my way of thinking.

Melancholic. Homesick. Silent. In my way of feeling." (no.6)

"My main point is that I am very determined, very determined. (...) at the same time that I am very determined I am very insecure. I am very sentimental, very very much, I don't know how to be rational, for me to be rational I have to work hard (...) also at the same time, I am very ambitious, I think it comes with my trait of determination, if I want to do something I want to do the best thing, I want to be in the best place, I always want the best." (no.4)

One common point among most of the interviewees is the awareness that, although they act transparently, their self-image is not always perceived in the same way by other people, which often causes them to feel misunderstood by society. This feeling of being misunderstood is precisely the theme of Cara estranho (Strange man), one of the band's songs most cited by the interviewees because of its importance and representativeness. Interviewees 2 and 11, respectively, stated the following: 
[Do you think that image that you described there now is exactly the one you pass or do you end up transmitting another image?] "I think it's a mix. I think it leaves a mix of what we want to be, of what we never show to the other $100 \%$ and what we really are, so I don't know, it's perception, I think that sometimes it is a mix of everything. "

"They see a bit beyond what it actually is perhaps, you understand? It is an image that has a certain linearity but it is a little distorted..."

Through the interviews, it could be seen that the band's fans are people with personalities that are generally shyer, isolated, and with a tendency to reflect on the various themes of life in a lyrical and romanticized way, in this way seeking their personal development. Moreover, their personalities have traits similar to the behaviors and characters that belong to the band's lyrics, probably a factor of congruence between identities through music (Larsen, Lawson, \& Todd, 2009).

\section{The mature fan and the relationship with the band}

The relationship with music was always passionately presented by the interviewees, either through their professional relationship (some work as musicians), or through the sense of completeness that music brings to the interviewees' lives. One common characteristic presented is eclecticism, as many reported listening to various genres of music - a fact that matches the band's mix of genres and rhythms.

In relation to the initial contact with the songs of Los Hermanos, this approximation was found to mostly occur due to the influence of people who were socially close. "[...] I had a friend who was a big fan, and he showed me the CD, and I listened to it and really liked it." (Interviewee no. 10). Audiovisual media and specialty stores were also mentioned.

In a post to the band's official community (@Los.Hermanos.Oficial) on Facebook, one of the fans commented about seeking to influence others to like the band:

"Los Hermanos is a soundtrack in every moment of my life, in the good times and the bad. I've influenced my wife and my 20 year-old stepson to be fans. Next to be co-opted is Bia, my 7-year old daughter..."(no.17)

Fans of Los Hermanos seem to have a somewhat mature relationship with the band, adopting a somewhat blasé stance toward the group, with even a bit of apprehension about bothering the musicians. We can see this attitude in the comment made by a fan in a post on the band's official community (@Los.Hermanos.Oficial) on Facebook:

"In 2015 I had the opportunity to see a concert of this wonderful band that was already a soundtrack and will continue to be at various moments of my life. On the same day of the concert, I saw Rodrigo Amarante leave the hotel and go into a restaurant, but I froze and watched him go past. The feeling was incredible, but it surely would have been better if I had the courage to go and talk to him." (M.E.F)

Thus, fans end up being less fixated on the artists themselves than on the songs. In an interview with the Multishow television network, Marcelo Camelo stated that people have a very easygoing and cordial relationship with the band, even the more enthusiastic fans, who tattoo their own skin with song lyrics and symbols related to the band. According to him, "they like the music very much, the music keeps them company, and this does not necessarily affect us [the musicians of the band]; it's a relationship that people have with the music."

Therefore, this characteristic of a "mature fan" seems to be related to both the age of the participants and the length of the relationship with the band, as well as the relationship fixated less on the persona of the artist and more on the art created. This type of fan has characteristics that diverge from various studies on the fan-artist relationship in the current musical world; for example, the studies of Click and Holladay (2013) about Lady Gaga fans and the study of Nuttall et.al (2011). In these studies, with younger fans and artists who are in vogue, the focus on the artist's persona is much greater - the fan-artist relationship is enhanced by direct contact through social networks such as 
Twitter and Instagram, and the relationship between the fans in the tribes is intense, both personally and digitally.

\title{
Image and relationship with other fans
}

Regarding the way in which the interviewees characterize the fans of Los Hermanos, some concepts based on objects such as clothes and accessories related to the aesthetics of the musicians were presented; however, a point of convergence was that, currently, there does not seem to be an aesthetic pattern for fans of the band. From their point of view, there is only the trait of being obsessed by the band, regarding both the possession of materials related to the band, as well as the demonstration of knowledge of the band and defending against those who do not appreciate the band. Thus, interviewees 3 and 5, respectively, stated the following:

\begin{abstract}
"It's very monotonous to talk about, there are a lot of people with a vision of Los Hermanos fans as having big beards, checked shirts, drinking strong liquor, and smoking. But I think nowadays there is no specific feature, you know [...] there is no standard style, no. "
\end{abstract}

"for me, someone either likes or doesn't like. [...] I think a true Los Hermanos fan is passionate, listens to the lyrics, understands the lyrics, makes their own interpretation, has all the albums, and wants to buy the LP, you know?"

The lack of a standard aesthetic or identity that characterizes today's fans converges with the ideas of Hall (2006) and Ortiz (2006) in stating that, in essence, the old concepts of identity have undergone modifications, fragmenting the modern individual, who until now had been seen as a single and immutable subject. In the view of Ortiz (2006, p.8), "there is no authentic identity, but rather a plurality of identities, created by different social groups at different historical moments."

Although the interviewees stated that there is no aesthetic pattern characteristic of the band's fans, in the behavioral field, the eclecticism in musical taste, the romanticism, the refined culture, and the search for a reflection on daily themes were indicated as common traits among them.

Contact with other fans is also common - the interviewees have maintained relationships with old friends who have also liked the band ever since it was active. However, there is little interaction in virtual communities, which runs counter to the considerations of Belk (2013) about increasing possibilities for the extension of the self and social interaction through the development of resources such as the internet and social networks. Most of the study participants do not seem to use digital media to either turn their privacy into a more public presentation of themselves or seek to relate more closely with their idols.

As for the recognition of being a fan, a large number of the interviewees reported that the people with whom they coexist do not recognize this status as something positive. The other half claimed to have friends who also like the band, albeit to a lesser extent. Many stated that the fact that the band split up has ended up diminishing the expressions of appreciation or dislike in the present day. Perhaps the fact that they have long been recognized as fans of the band diminishes the need for affirmation and extension of the self through physical products or in the digital environment.

\section{Identity passed on by the band}

In this section, the main data obtained regarding the image of the band through different perspectives, the lyrics of their songs, and the perceptions and reasons of those who do not like the band are presented and discussed.

\section{Image of the band}

According to the interviewees, the band Los Hermanos is characterized by the diversity of its music, which addresses various themes related to daily life through different rhythms that move from rock to samba, with the use of instruments that are not very conventional for bands of the same genre. 
Asked about how they would describe the band to someone who does not know it, they stated the following:

"A band that has great hits for any occasion in your life you could imagine, because they know how to get you up and how to calm you down. Songs that will stay in your head and that will make your life different." (Interviewee no. 9)

"I would say that it is a band with a lot of intensity, a lot of authenticity, a versatile band with virtuous musicians." (Interviewee no. 14)

"It's a band that uses bossa nova chords, but with overdrive on!" (Interviewee no. 19)

From a perspective within the band, the response of vocalist Marcelo Camelo about the identity and the most striking traits of the band was as follows:

"Each of us will have a different answer. I think this diversity in the elements that make up the band, the four of us, is our main strength. I also think we have a personalness in the discourse that escaped a little - at some point - from what was being done in Brazil, and this brought an audience that has accompanied us to this day and made us a hallmark of a force that has attracted young people from different generations as time has gone by."

Thus, from the perspective of the fans and one of its members, the image of Los Hermanos, or the reflection of its identity, is marked by the diversity of themes and rhythms in the songs (e.g., the mixture of samba and rock), and this diversity is almost always characterized by personalness and particularity in addressing daily issues and the use of a certain lyricism in the compositions.

\section{The song lyrics}

The band's lyrics are a great identification reference for most of the fans, and the passion for the group is intense and incorporated into daily life and interpersonal relationships.

According to Ter Bogt et al. (2011), listeners are influenced by lyrics and ideas expressed by artists in addition to identifying with the image of an artist or band. Identification can take the form of recognizing oneself in a band's lyrics, style, or presentation.

The diversity of themes in song lyrics - a characteristic indicated in various interviews ends up generating a great plurality in the choice of a song with which the interviewee identifies the most. The song $O$ velho e o moço (The old man and the young man) was most-cited as the favorite and, therefore, the song that best represents them.

Encouraging reflection in the face of various situations is, apparently, the main impact of Los Hermanos' songs on the fans:

"I think they represent a lot of mundane problems, the problems that we feel every day." (no. 10)

"[...] they teach us to value what we have without ceasing to dream, to appreciate the good moments of life and to be stronger for the bad moments that will come." (no. 21)

"Camelo talks more about relationships, whether it's man/woman, mother/child etc. Amarante is more nonsense." (no. 17)

The findings about the relationship of the fans with the band are convergent with the opinion of vocalist Marcelo Camelo, when asked about the factors that to this day have most attracted the fans to the work of the band:

"I think it has always been through the work itself. The lyrics of a more personal nature and with a message of love, of acceptance of difference, and of fragility, went very much against the common sense of the musical scene of the time, especially in our area of youth music, with tendencies toward rock. This helped to distinguish the band from others." 
According to Anaz (2013), the various musical genres have collaborated in the formation of "tribes" whose participants share the imaginary that emerges from the songs, establishing processes of cultural identification around this imaginary. Such a condition can be identified in the fans interviewed, through the great demonstration of appreciation for the messages transmitted by the group's songs. Therefore, the success of the songs among the band's fans comes from their plurality of themes related to daily life, which ends up stimulating reflection in the listener. Thus, the lyrics seem to be one of the most important factors in the construction of the image of the band and, consequently, one of the main points of connection between the band and the fans in the design of identity.

In this sense, the concerts are the main place where fans act as prosumers, according to the concepts of Chen (2018) and Fuschillo (2020). When singing the songs along with the band (a distinctive aspect of the group's concerts), as well as making requests for songs, they end up becoming part of the construction of the concerts as a cultural "product". In this sense, the vocalist Marcelo Camelo explains: "there was the strength of the songs, which were always made in order to invite singing together and encourage the affective participation of the audience".

\section{Congruence and self extension}

In this section, questions are raised regarding the congruence between the self-image of the interviewed fans and their image of the band, as well as the extension of the self through the rituals of consumption of products and services associated with the group. There is also an emerging category of the study, represented by the nostalgia generated with the end of the band and stimulated by the sporadic tours that have occurred after the band's separation.

\section{Congruence between self-image and the image of the band}

Listening to the songs of Los Hermanos is still a habit for the interviewees, despite the ending of the band or their "indefinite hiatus". For most of them, the moment they enjoy listening to the songs is when they are alone thinking about life, being quiet, or having some problem to solve. They do this by seeking a message that strengthens them, which indicates which path to follow or simply that it is necessary to experience that moment.

The appreciation for the band and for the messages transmitted through their songs can also be perceived in posts on the band's official community on Facebook:

"Damn, the best band! The best memories... [...] Poetry! I once celebrated a birthday at one of their concerts... [...]I've danced to Ana Júlia, I've cried listening to Quem Sabe (Who knows), I've reflected listening to $O$ Vento (The Wind) ...I've gone to [ALL] the places and feelings listening to [ALL] the songs. [ALL] have hallmarks, [ALL] have meaning." (M.S.)

This form of support provided by music is corroborated by Ter Bogt et al. (2011), who stated that the practice of listening to music is used as a form of mood management and, therefore, it can help people manage problems, such as depression and anxiety, or deal with feelings of alienation and anger.

For all the work developed, the band ended up assuming a great representation and reference in the lives of the fans, either by bringing to the fore memories of past periods of their existence or, further still, by complementing their emotions, whether good or bad:

"Hey, they represent a phase in my life, a phase of transition in my life. It represented that formation of character as a teenager, that implication of some doubts you have when you're a teenager." (no. 3)

All the identification of the fans with the band and the representativeness that it assumes in relation to their personalities occurs because the music can be used to represent the self of an individual when there is congruence between the image of the music of an artist or band and the aspects of the self of the person, that is, their self-image (Larsen, Lawson, \& Todd, 2009). As an example of this correlation, the interviews showed that the reflective and romantic pattern of the personality of the fans is identified with the same characteristics that are present in the group's 
compositions. From this identification process, the fans end up appropriating songs and objects related to the artist or band, using them to reaffirm their own identity.

A great counterpoint to the legion of fans of the band Los Hermanos is the large group of people who do not like the band, the anti-fans or haters (Obiegbu, Larsen, \& Ellis, 2019). In the point of view those who claim to be fans, there are several reasons alleged by those who do not appreciate the work of the band, but some aspects stand out: the extreme reflection proposed by the songs, the (negative) myths generated around the band, as well as the posture of the group members. As the interviewee $n .4$ states:

"Ah, a tiring, depressing band, like: oh, I'm so lazy to hear that. It's a rather dramatic band. I think that's the vision they have." (no. 4)

The fact of not like the band is explained by Larsen, Lawson and Todd (2009) as a case of incongruity between the band's image and a person's self-image, which leads up to the expression of disgust for some artist or type of music. There are several posts on social networks with phrases like "Los Hermanos is boring like Monday", "Los Hermanos is more boring than dancing with your sister at a party", or even the presentation of fake news about the band, which, on the other side, is an evidence of the strength of the identity built by the band and their fans.

\section{Extension of the self through consumption rituals}

Even after their separation, Los Hermanos has been touring on a recurring basis, in addition to commercializing products on its official website. T-shirts, mugs, posters, and keychains are made available to the public in an attempt to maintain the relationship with them, perpetuating the extension of the self of the fans through products. This strategy of maintaining the relationship through products also includes developments such as the offering of rompers and plush dolls (products typical of a children's audience), which is consistent with the fact that most of the fans, and especially those interviewed in this study, belong to an age group that conventionally is likely to have children.

When asked by the researcher about how the musicians conceive, understand, and end up managing the marketing issues (consumption potential of the fans) even today, vocalist Marcelo Camelo responded as follows:

"We do not participate in anything except the records. The most we do is approve or disapprove ideas."

According to Niemeyer (2014), fragmented availability gives the listener renewed enjoyment when experiencing past events, whether through remixed albums, reunion tours, or even holograms that bring back to the stage the bodies and voices of artists. Staging authenticity to assure consumers that they will retain a glimpse of what time cannot give them is, therefore, a constant goal in the ways of rethinking and promoting a particular culture and reaffirming the tastes related to it.

In relation to the consumption rituals related to the songs of Los Hermanos, most interviewees prefer to listen to the songs through digital media such as mp3s or through sites and applications such as YouTube and Spotify, even if they have CDs, DVDs, and vinyl records, which are usually stored like treasure. Maintaining these band-related products - although they are no longer used - can be explained by the concepts of Barboza and Ayrosa (2013) and Belk (1988), who stated that the goods that are part of the extended self provide us with a personal archive like a museum, which reflects our history and our changes in life. We can perceive this situation in the statement of interviewee no. 2:

"[So, you use the MP3 more, you don't have contact with the physical format, do you?] No, it's safely stored. I even have an autographed CD of the guys. The first CD."

The most consumption of products and services by the fans is represented by CDs, DVDs, vinyl records, T-shirts and, in particular, the band's concerts. This consumption, especially of products, was 
more dynamic when the band was still playing. Today, the spending is limited to the sporadic tour concerts that the band does - the last one of which occurred approximately two years ago. Regarding these consumption patterns, interviewee no. 9 said the following:

\section{"CDs, DVDs, shirts, and the concerts were what I mostly consumed. I have two LPs."}

However, when asked if they would consume something related to the band available on the market, the respondents mostly replied that they would be willing to buy - something difficult to prove since many were not even aware that the band's official product store is still operating.

Only two of the interviewees stated that they had adopted a style that, in some way, is related to the aesthetics of the band - one of them has a tattoo with reference to the lyrics of a song of the band. All the others do not wear clothing or accessories common to group members or fans, or, if they do, they credit other references, not Los Hermanos.

For Belk (1988) and Boorstin (1973), the use of clothing, adornments, accessories, and tattoos are a means of distinguishing and identifying with a particular group - a way of defining the participation through shared consumption symbols.

Regardless, most of the respondents stated that, in some way, they publicly show that they are fans of the band, as stated by interviewee no. 8:

\section{"When the right moment arises, I'll talk about the guys. I'll mention [the band]." (no. 8)}

Thus, it can be seen that the public demonstration of being a fan of the band is achieved more through discourse than objects (clothing, accessories) that refer to the aesthetics of the band.

\section{Nostalgia and the myth of the band that split up}

In relation to memories motivated by music, Van der Hoeven (2015) stated that in the social and collective context, songs from the past can bring memories to the fore and generate nostalgia, which also provides individuals with a feeling of belonging to a specific group with which they have an affinity. This fact becomes even more important in the case of some bands that take on mythical status because they ended prematurely, thus fueling a culture of nostalgia that is capitalized on in return concerts or the launching of new material years after their dissolution (Barcinski, 2016).

Furthermore, the targets and levels of nostalgic consumption experienced by different consumers depend on the changes that occur over time, which are, therefore, associated with age. One conventional notion is that adolescence represents a formative time for musical preferences, thus, the most important element that determines people's musical tastes is their age (Holbrook, 1993). These arguments can serve as a basis for the analysis of Los Hermanos, including the fact that most of the fans interviewed experienced their adolescence during the height of the band.

When questioned about whether the band's separation in 2007 affected the passion of the fans, the interviewees said that the split, although traumatic, further strengthened the relationship with the group, including increasing audience numbers in return concerts.

One of the fans interviewed presented a very peculiar situation, which is the awakening of old memories through the concerts that occurred after the dissolution of the band:

"But there's something very curious there man. There was this concert two years ago, and I bought the tickets without feeling excited [...] the time came and I was delirious, singing all the lyrics, jumping like crazy; so you see that the band still has an impact on you..." (Interviewee no. 13)

Finally, it can be seen that the band Los Hermanos still arouses the admiration of fans, which reinforces the practices of consuming products and services associated with the group. The formation and representation of the identities of the fans are also intensified by the admiration for the songs and the image of the band, providing an identification by the public with the group. 


\section{DISCUSSION AND CONCLUSIONS}

The self-image of individuals greatly reflects the dimensions of their identity. In the case of the fans interviewed in this study, the main features revealed were their shyness or isolation in relation to other people, determination in achieving their goals, and reflection in the midst of various everyday situations - often in a lyrical and romanticized way. Despite the recognition of these characteristics, most of them are aware that their image of themselves is not always perceived the same way by other people.

One peculiar characteristic found in these fans is their greater fixation on the songs themselves, and not so much on the artists of the group, with them developing a certain distance as a form of protection of the musicians. The way in which the fans perceive their peers today is no longer based on objects such as clothing and accessories related to the aesthetics of the musicians but rather on the trait of being obsessed with the band, knowing and appreciating the work, as well as the imaginary created by the band. For the band's image, the interviewees characterized it through the diversity of their songs, which cover various themes regarding daily life, using different rhythms and instruments that are not very conventional for bands of the same genre.

The separation of the band in 2007 did not diminish the appreciation for the group - on the contrary, it stimulated even more the admiration and the awakening of memories through the reunion shows after the dissolution. The nostalgia generated by the dissolution of the band captivated the fans, reinforcing the practices of consuming products and services associated with the group.

This case study facilitated our understanding of the market implications related to the relationship between artist and fans. A public with specific characteristics - distinct from the characteristics of the music market in general - could be seen; however, having their needs met, they end up identifying faithfully with the musical group. This consumer/fan, whom we call a "mature fan", has a passionate relationship with the artist; however, the need to demonstrate their fanaticism and the means they use for this seem to differ from that of young fans. These differences should be explored in future studies, especially in styles such as rock and MPB, in which older artists tend to be more valued but have had difficulty updating themselves.

Therefore, even in the music market, in which the creativity of musicians seems to guide production, attending to a particular segment, understanding its needs, and planning the products and services that are appropriate to it generates great fidelity on the part of the consumer. With the plurality of artists and bands today, it is necessary to understand the identity of the fans, as well as their tastes and preferences. There is a conflict between art and business; however, it must be resolved through strategies that accommodate the interests of both sides of the equation.

As theoretical contributions, this study expanded the discussion represented by the conceptual model of music consumption proposed by Larsen, Lawson and Todd (2009), incorporating the analysis of the consumption rituals and the forms of extension of the self through music. Through the study's results, it was possible to discuss issues related to these two aspects of consumption in the specific context of the fans of the band Los Hermanos, which could also be explored in conjunction with other artists or bands.

Additionally, the study presented an important aspect of consumption in the music industry, which is the congruence of the identity of individuals with the image of the artist or band. The consumption of goods and services by fans is directly related to the level and form of this congruence, since the identification of people with their idols ends up defining their propensity to consume products and services related to the artist or musical group.

The study also enabled the identification of elements related to the concept of nostalgia presented by Holbrook (1993), highlighting the importance of this factor in the consumption choices in the cultural field. Additionally, the concept of the "mature fan" - proposed in this study to characterize a fan who has a long-standing relationship with an artist and a bond based more on the work than on the artist's persona, and who does not have such a need to visually express their identity as a fan — should be explored and developed in subsequent studies. 


\section{References}

Anaz, S. A. L. (2013). O imaginário da canção midiática como vetor de identificação cultural. Sessões do Imaginário, 18(30), 48-56.

Arnould, E. J., \& Thompson, C. J. (2005) Consumer Culture Theory (CCT): Twenty Years of Research. Journal of Consumer Research, 31(4), 868-882.

Barboza, R. A., \& Ayrosa, E. A. T. (2013). Um estudo empírico sobre a construção da identidade social do consumidor de Toy Art. Revista de Ciências da Administração, 1(1), 11-21. https://doi.org/10.5007/2175-8077.2013v15n37p11

Barcinski, A. (2016). Teenage Fanclub e a maldição das bandas que insistem em sobreviver. Retrieved from https://blogdobarcinski.blogosfera.uol.com.br/2016/10/17/teenage-fanclub-e-amaldicao-das-bandas-que-insistem-em-sobreviver

Belk, R. W. (1988). Possessions and the extended self. Journal of consumer research, 15(2), 139-168. https://doi.org/10.1086/209154

Belk, R. W. (2013). Extended self in a digital world. Journal of Consumer Research, 40(3), 477-500. https://doi.org/10.1086/671052

Boer, D., Fischer, R., Tekman, H. G., Abubakar, A., Njenga, J., \& Zenger, M. (2012). Young people's topography of musical functions: Personal, social and cultural experiences with music across genders and six societies. International Journal of Psychology, 47(5), 355-369. https://doi.org/10.1080/00207594.2012.656128

Boorstin, D. J. (1973). The Americans: The democratic experience. New York: Random House.

Cavalcanti, R. C. T., de Souza-Leão, A. L. M., \& Moura, B. M. (2021). Fan Affirmation: Alethurgy on an Indie Music Fandom. Revista de Administração Contemporânea, 25(5), e190395-e190395.

Chen, Z. T. (2018). Poetic prosumption of animation, comic, game and novel in a post-socialist China: A case of a popular video-sharing social media Bilibili as heterotopia. Journal of Consumer Culture, 1469540518787574.

Click, M. A., Lee, H., \& Holladay, H. W. (2013). Making monsters: Lady Gaga, fan identification, and social media. Popular Music and Society, 36(3), 360-379. https://doi.org/10.1080/03007766.2013.798546

de Souza-Leão, A. L. M., Moura, B. M., da Silva Nunes, W. K., Henrique, V. D. M. R., \& de Santana, I. R. C. (2020). No shame to play: Ludic prosumption on Brazilian fanvideos. Revista de Gestão.

Denzin, N. K., Lincoln, Y. S. (4.ed.). (2011). The handbook of qualitative research. Sage.

Devlin, M., Billings, A. C., \& Leeper, J. (2016). Fighting fandom: How fan identity influences selfreported and physiological arousal during exposure to violent sports imagery. Journal of Sports Media, 11(2), 159-185. https://doi.org/10.1353/jsm.2016.0016

Douglas, M., \& Isherwood, B. (2002). The world of goods. Routledge. https://doi.org/10.4324/9780203434857

Duffett, M. (2015). Fan practices. Popular Music and Society, 38(1), 1-6. https://doi.org/10.1080/03007766.2014.973764

Fuschillo, G. (2020). Fans, fandoms, or fanaticism? Journal of Consumer Culture, 20(3), 347-365.

Gaião, B. F. da S., de Souza, I. L., \& de Souza Leão, A. L. M. (2012). Consumer culture theory (CCT) já é uma escola de pensamento em marketing? RAE-Revista de Administração de Empresas, 52(3), 330-344.

Gajanigo, P. R. (2016). Delicadeza e conflito na música: Los Hermanos e outras ressonâncias. ALCEU, 16(32), 136-152.

Guschwan, M. (2012) Fandom, brandom and the limits of participatory culture. Journal of Consumer Culture, 12 (1), 19-40. https://doi.org/10.1177\%2F1469540512438154

Hall, S. (2006). A identidade cultural na pós-modernidade. TupyKurumin.

Hellekson, K. The fan experience. In: Booth, P. (2018). A Companion to Media Fandom and Fan Studies. John Wiley \& Sons.

Holbrook, M. B. (1993). Nostalgia and consumption preferences: Some emerging patterns of consumer tastes. Journal of Consumer research, 20(2), 245-256. https://doi.org/10.1086/209346 
Larsen, G., Lawson, R., \& Todd, S. (2009). The consumption of music as self-representation in social interaction. Australasian Marketing Journal (AMJ), 17(1), 16-26. https://doi.org/10.1016/j.ausmj.2009.01.006

Mascarenhas, A. M. (2016). Utopia, heterotopia e nostalgia na performance dublada de música pop. Vozes e Diálogo, 15(02).

McCracken, G. (1988). The long interview (Qualitative Research Methods). London: Sage.

Miles, M. B., Huberman, A. M., \& Saldaña, J. (2018). Qualitative data analysis: A methods sourcebook. Sage publications.

Niemeyer, K. (2014). Media and nostalgia: Yearning for the past, present and future. Springer. https://doi.org/10.1057/9781137375889

Nuttall, P., Arnold, S., Carless, L., Crockford, L., Finnamore, K., Frazier, R., \& Hill, A. (2011). Understanding music consumption through a tribal lens. Journal of Retailing and Consumer Services, 18(2), 152-159. https://doi.org/10.1016/j.jretconser.2010.12.007

Obiegbu, C. J., Larsen, G., \& Ellis, N. (2019). The critical music fan: the role of criticality in collective constructions of brand loyalty. Arts and the Market.

Ortiz, R. (2006). Cultura brasileira e identidade nacional. In Cultura brasileira e identidade nacional. Brasiliense.

Reijnders, S., Zwaan, K., \& Duits, L. (Eds.). (2014). The Ashgate research companion to fan cultures. Ashgate Publishing, Ltd.

Suess, R. C. (2016). Uma leitura do estado de Goiás (Brasil): elos entre música, território e lugar. Cuadernos de Geografía: Revista Colombiana de Geografía, 25(1), 195-206. http://dx.doi.org/10.15446/rcdg.v25n1.48152

Sugihartati, R. (2020). Youth fans of global popular culture: Between prosumer and free digital labourer. Journal of Consumer Culture, 20(3), 305-323.

Ter Bogt, T. F., Mulder, J., Raaijmakers, Q. A., \& Nic Gabhainn, S. (2011). Moved by music: A typology of $\begin{array}{lllll}\text { music listeners. Psychology of } & \text { Music, 39(2), }\end{array}$ https://doi.org/10.1177/0305735610370223

Ulusoy, E. (2016). Subcultural escapades via music consumption: Identity transformations and extraordinary experiences in Dionysian music subcultures. Journal of Business Research, 69(1), 244-254. https://doi.org/10.1016/j.jbusres.2015.07.037

Van der Hoeven, A. (2018). Narratives of popular music heritage and cultural identity: The affordances and constraints of popular music memories. European Journal of Cultural Studies, 21(2), 207222. https://doi.org/10.1177\%2F1367549415609328 